\title{
PENGARUH MODEL PROCESS ORIENTED GUIDED INQUIRY LEARNING (POGIL) DENGAN MEDIA KARTU MASALAH TERHADAP PEMAHAMAN KONSEP DAN AKTIVITAS BELAJAR SISWA PADA MATERI MOMENTUM DAN IMPULS DI SMA.
}

\author{
1)Cholifatur Rosidah , 1)Sudarti , 1)Maryani \\ 1)Program Studi Pendidikan Fisika FKIP Universitas Jember \\ Email: cholifaturrosidah18@gmail.com
}

\begin{abstract}
The type of this research was experimental research with post-test only control group design in SMA Negeri 1 Panji Situbondo 2016/2017. This research purposed to know the influence of POGIL models with media card problems with understanding students and student learning activities. Determination of research sample is used cluster random sampling, X MIA 4 as experiment class and X MIA 2 as control class. The technique of data analysis were independent sample t-test with program SPSS 22. Based on analysis of Mann-Whitney test result, showed that model of POGIL with media card problems have significantly effect to the understanding of the student's concept. Based on the analysis of the independent sample t-test results showed that model of POGIL with media card problems have significantly effect to student learning activities.
\end{abstract}

Keyword: POGIL, understanding the concept, student learning activities

\section{PENDAHULUAN}

Fisika merupakan materi sains yang hakikatnya adalah ilmu yang mempelajari tentang alam dan gejalanya, yang terdiri atas proses dan produk. Proses yang dimaksud adalah proses ilmiah, yaitu proses yang langkah-langkahnya menggunakan prosedur atau metode ilmiah. Produk sains yang dimaksud adalah pengetahuan yang dapat berupa fakta, konsep, prosedur, teori, atau hukum (Sutarto dan Indrawati, 2013:59). Pembelajaran fisika dikelas masih menghadapi beberapa masalah. Berdasarkan wawancara kepada guru di beberapa sekolah, diantaranya SMA Negeri 1 Situbondo, SMA Negeri 1 Panji Situbondo, SMA Negeri 1 Panarukan Situbondo, dan
SMA Negeri 1 Kapongan Situbondo yang dapat disimpulkan secara umum bahwa siswa masih kesulitan dalam memahami konsep pada materi fisika khususnya materi momentum impuls masih lemah. Selain itu, wawancara juga dilakukan pada 7 siswa di sekolah tersebut, bahwa siswa masih mengalami kesulitan dalam mengerjakan soal. Hal ini ditunjukkan dengan hasil ulangan harian yang diperoleh siswa masih dibawah Kriteria Ketuntasan Minimal (KKM).

Materi momentum impuls adalah salah satu materi fisika yang diajarkan di SMA/MA. Dalam mempelajari materi ini, siswa juga kerap melakukan kesalahan dalam mengerjakan soal-soal yang berkaitan dengan materi. Menurut Wijayanti et al 
(2010), bahwa siswa mengalami kesulitan belajar fisika meliputi memahami materi, mengaitkan hubungan antar konsep, mengerti rumus, dan mengoperasikan rumus untuk menyelesaikan soal. Hal tersebut senada dengan Rusilowati (2006), yang menyatakan bahwa penyebab kesulitan belajar fisika adalah adanya kesalahan dalam pemahaman konsep, kemampuan matematis, dan kemampuan mengkonversi satuan.

Pemahaman konsep sangat dibutuhkan oleh siswa untuk menyelesaikan suatu kasus atau masalah. Dengan memahami konsep siswa akan lebih mudah mengerjakan soal walaupun telah divariasikan (Darmayanti et al, 2013). Menurut Hamdani et al (2012), pemahaman konsep adalah kemampuan menangkap pengertian-pengertian seperti mampu mengungkapkan suatu materi yang disajikan kedalam bentuk yang lebih dipahami (translation), mampu memberikan interpretasi (interpretation), dan mampu mengaplikasikannya (extrapolation). Instrumen penilaian yang mengukur kemampuan pemahaman konsep matematis mengacu pada indikator pencapaian pemahaman konsep. Menurut Herdy (dalam Ferdianto dan Ghany, 2014: 50) ada tiga macam pemahaman yaitu: 1) pemahaman translasi (tranlation) digunakan untuk menyampaikan informasi dengan bahasa dan bentuk yang lain dan menyangkut pemberian makna dari suatu informasi yang bervariasi; 2) pemahaman interpretasi (interpretasi) digunakan untuk menafsirkan maksud dari bacaan, mencakup pemahaman suatu informasi dari sebuah ide; 3) pemahaman ekstraplorasi dan pembuatan ekstrapolasi (ekstrapolation), mencakup estimasi dan prediksi yang didasarkan pada sebuah pemikiran, gambaran kondisi dari suatu informasi, juga mencakup pembuatan kesimpulan.

Observasi dilakukan di sekolah SMA Negeri 1 Panji Situbondo, dari hasil observasi tersebut terdapat permasalahan dalam pembelajaran fisika. Permasalahan itu meliputi: 1) aktivitas siswa yang termasuk dalam oral activities yaitu siswa kurang aktif dalam bertanya maupun menjawab pertanyaan guru, 2) siswa mengalami kesulitan dalam mengerjakan soal dan kesulitan dalam menentukan rumus yang akan digunakan untuk menyelesaikan soal, 3) beberapa siswa tidak tanggung jawab terhadap tugas kelompok. Hal ini ditunjukkan pada saat siswa diberi tugas kelompok hanya sebagian anggota saja yang mengerjakan.

Arum et al (2017), menyatakan bahwa aktivitas belajar merupakan suatu kegiatan yang dilakukan untuk menghasilkan perubahan pengetahuanpengetahuan, nilai-nilai sikap dan keterampilan pada siswa sebagai latihan yang dilaksanakan secara sengaja. Menurut Jumarni et al (2013), aktivitas belajar merupakan segala kegiatan yang dilakukan siswa pada saat proses pembelajaran berlangsung. Kegiatan pembelajaran tidak akan berlangsung baik apabila tidak ada aktivitas belajar. Berdasarkan permasalahan yang dialami oleh siswa, perlu adanya suatu penerapan model serta media pembelajaran yang mampu memberi kesempatan kepada siswa untuk menemukan sendiri pengetahuannya serta berperan aktif dalam pembelajaran sehingga mampu memahami konsep dengan baik.

Model pembelajaran POGIL dengan media kartu masalah merupakan model pembelajaran aktif dengan beberapa kelompok kecil yang terdiri dari 3-4 siswa dengan media kartu masalah sebagai media pembelajaran. Dalam kelas POGIL, siswa bekerja dalam kelompok yang bertujuan penguasaan konsep (Widyaningsih et al, 2012). widiawati

Menurut Ningsih et al (2012), adapun peran-peran dalam kelompok POGIL yaitu (1) manager, mengatur kelompok, termasuk 
menjamin anggota kelompok lainnya melaksanakan peran masing-masing dan seluruhnya ikut berkontribusi dalam kelompok; (2) spokesperson (juru bicara), mempresentasikan laporan secara verbal atas nama kelompok kepada seluruh siswa di kelas; (3) recorder (notulen), mencatat nama dan peran dari anggota kelompok tiap sesi, serta mencatat jawaban dan penjelasan kelompok; (4) strategy analyst, mengawasi dan mengomentari dinamika kelompok, sikap anggota kelompok dalam menghargai proses pembelajaran dan strategi yang dilakukan kelompok untuk memecahkan masalah.

Berdasarkan uraian tentang pemahaman konsep dan aktivitas belajar siswa rendah, maka penelitian ini membahas tentang "Pengaruh Model Pembelajaran Process Oriented Guided Inquiry Learning (POGIL) dengan Media Kartu Masalah Terhadap Pemahaman Konsep dan Aktivitas Belajar Siswa pada Materi Momentum dan Impuls di SMA". Tujuan penelitian ini antara lain: (1) untuk mengkaji pengaruh model Process Oriented Guided Inquiry Learning (POGIL) dengan media kartu masalah terhadap pemahaman konsep momentum dan impuls di SMA; (2) untuk mengkaji pengaruh model Process Oriented Guided Inquiry Learning (POGIL) dengan media kartu masalah terhadap aktivitas belajar siswa momentum dan impuls di SMA.

\section{METODE}

Jenis penelitian ini adalah penelitian eksperimen dengan menggunakan post-test only control group design. Sebelum menentukan sampel, dilakukan uji homogenitas terhadap populasi kelas X MIA sebanyak 4 kelas dan diambil 2 kelas sebagai kelas eksperimen dan kelas kontrol. Penentuan sampel penelitian menggunakan cluster random sampling Menurut Wahyuni
(2011:4), kriteria pengujian yang digunakan adalah sebagai berikut:

a. Nilai signifikansi $(\mathrm{Sig})<0,05$ memiliki arti bahwa data yang berasal dari populasi memiliki varians tidak serupa (tidak homogen).

b. Nilai signifikansi $(\mathrm{Sig})>0,05$ memiliki arti bahwa data yang berasal dari populasi memiliki varians serupa (homogen).

Teknik pengumpulan data dalam penelitian ini meliputi tes, observasi, dokumentasi, dan wawancara. Variabel bebas dalam penelitian ini adalah model pembelajaran POGIL dengan media kartu masalah, sedangkan variabel terikat dalam penelitian ini adalah pemahaman konsep dan aktivitas belajar siswa. Analisis data penelitian ini menggunakan analisis independent sample t-test dengan bantuan program SPSS 22. melalui pengujian hipotesis one-tailed atau uji pihak kanan pada taraf signifikansi 5\% (Sugiyono, 2016:97).

\section{HASIL DAN PEMBAHASAN}

Penelitian ini dilaksanakan di SMA Negeri 1 Panji Situbondo pada semester genap tahun ajaran 2016/2017 mulai 15 Mei 2017 sampai 3 Juni 2017 pada siswa kelas $\mathrm{X}$. Kelas eksperimen pada penelitian ini adalah kelas menggunakan model POGIL dengan media kartu masalah, sedangkan kelas kontrol menggunakan model pembelajaran yang biasa digunakan di sekolah. Sebelum melakukan penelitian terlebih dahulu menentukan populasi penelitian dengan menggunakan uji homogenitas pada kelas X MIA SMA Negeri 1 Panji Situbondo dengan menggunakan ulangan harian materi sebelumnya yaitu usaha dan energi.

Berdasarkan uji homogenitas melalui uji One Way Annova, diperoleh nilai signifikansi lebih besar dari 0,05 $(0,432>0,05)$ maka dapat disimpulkan 
bahwa populasi mempunyai kemampuan yang sama (homogen). Populasi yang sudah homogen digunakan untuk menentukan sampel penelitian dengan menggunakan metode cluster random sampling. Adapun kelas yang menjadi sampel penelitian adalah kelas X MIA 4 sebagai kelas eksperimen yang memiliki jumlah 35 dan kelas X MIA 2 sebagai kelas kontrol yang memiliki jumlah siswa 34.

Data pemahaman konsep siswa diperoleh melalui post-test yang dilakukan setelah kegiatan pembelajaran pada materi momentum dan impuls. Uji normalitas dilakukan sebelum melakukan uji independent sample t-test dengan bantuan program SPSS 22, hal ini dilakukan untuk mengetahui bahwa data yang dugunakan berasal dari daya yang memiliki varian sama, artinya data terdistribusi normal.

Berdasarkan uji normalitas diketahui kelompok data tersebut tidak terdistribusi normal. Karena data tidak terdistribusi normal maka uji t dilakukan dengan uji statistik nonparametrik yang setara dengan uji Independent Sample T-Test yaitu uji Mann-Whitney. Berdasarkan hasil uji Mannwhitney diketahui bahwa Sig.(2-tailed) adalah $0,000 \leq 0,05$ maka $H_{a}$ diterima dan $H_{0}$ ditolak, maka model POGIL dengan media kartu masalah berpengaruh signifikan terhadap pada pemahaman konsep siswa dalam pembelajaran fisika di SMA Negeri 1 Panji Situbondo. Ringkasan data rata-rata nilai pemahaman konsep siswa dapat dilihat pada Tabel 1 berikut.

Tabel 1. Rata-rata nilai pemahaman konsep

\begin{tabular}{|c|c|c|c|}
\hline No & Indikator & Eksperimen & Kontrol \\
\hline 1. & Menerjemahkan (Translation) & 84 & 68 \\
\hline 2. & Menginterpretasi (Interpretation) & 89 & 59 \\
\hline 3. & Mengekstrapolasi (Ekstrapolation) & 87 & 42 \\
\hline & Rata-rata & 87 & 56 \\
\hline
\end{tabular}

Dari Tabel 1 diketahui bahwa ratarata nilai pemahaman konsep siswa paling tinggi adalah indikator menginterpretasi (interpretation) dengan nilai 89 untuk kelas eksperimen dan indikator menerjemahkan (tranlation) dengan nilai 68 untuk kelas kontrol. Sedangkan rata-rata nilai pemahaman konsep terendah adalah indikator menerjemahkan (tranlation) dengan nilai 84 untuk kelas eksperimen dan indikator mengekstrapolasi (ekstrapolation) dengan nilai 42 untuk kelas kontrol. Berdasarkan rata-rata nilai pemahaman konsep siswa, jika dibandingkan antara kelas eksperimen dan kelas kontrol untuk setiap indikator pemahaman konsep siswa kelas eksperimen lebih baik daripada kelas kontrol. Dengan demikian dapat disimpulkan bahwa model POGIL dengan media kartu masalah berpengaruh signifikan terhadap pemahaman konsep siswa di SMA
Negeri 1 Panji Situbondo. Adapun urutan indikator pemahaman konsep siswa dari nilai tertinggi sampai terendah ditunjukkan pada Gambar 1 dibawah ini.

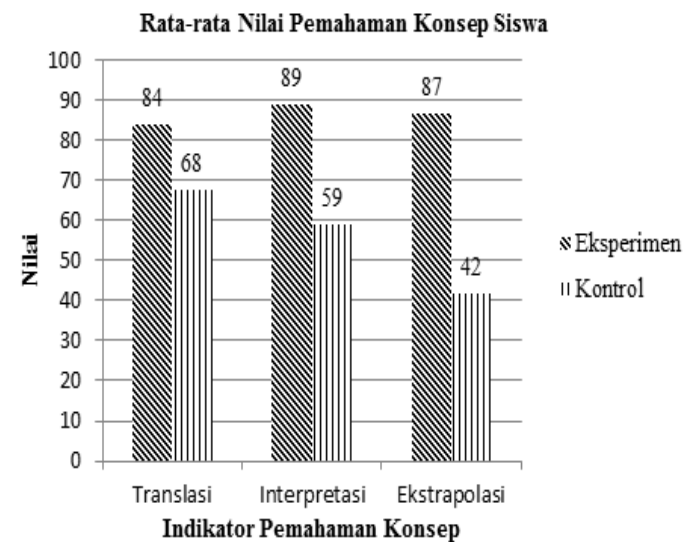

Gambar 1. Grafik rata-rata nilai pemahaman konsep siswa

Berdasarkan Gambar 1 dapat dilihat bahwa rata-rata nilai pemahaman konsep siswa kelas eksperimen tertinggi yaitu 
menginterpretasi, dan terendah yaitu menerjemahkan. Sedangkan rata-rata nilai pemahaman konsep siswa kelas kontrol tertinggi yaitu menerjemahkan, dan terendah yaitu mengekstrapolasi.

Pemahaman konsep siswa pada kelas eksperimen lebih baik daripada kelas kontrol. Pada kelas eksperimen siswa dihadapkan pada suatu permasalahan yang nyata melalui video demonstrasi dan menghubungkan pengetahuan sebelumnya terkait materi yang akan dipelajari, sehingga kemampuan siswa untuk menerjemahkan (translation) lebih baik daripada kelas kontrol. Kegiatan pembelajaran pada kelas eksperimen dilakukannya proses tanya jawab, mempresentasikan hasil diskusinya sesuai dengan peran masing-masing anggota kelompok, sehingga kemampuan siswa menginterpretasi lebih baik dari kelas kontrol. Selain itu, diakhir pembelajaran guru juga memberikan penguatan dari permasalahan yang telah diselesaikan sehingga kemampuan siswa untuk mengambil keputusan berupa menyimpulkan suatu permasalahan (extrapolation) lebih baik daripada kelas kontrol. Sedangkan di kelas kontrol pembelajaran menggunakan metode ceramah, siswa tidak dihadapkan pada suatu permasalahan yang nyata melalui video demonstrasi, tidak melakukan diskusi kelas untuk meningkatkan pemahaman konsep siswa, sehingga kemampuan siswa dalam menerjemahkan, menginterpretasi, dan mengekstrapolasi lebih rendah jika dibandingkan dengan kelas eksperimen.

Dengan menerapkan model POGIL yang merupakan elaborasi dari 3 komponen yaitu tim belajar, aktivitas inquiry terbimbing, dan metakognisi, siswa akan lebih mudah memahami konsep fisika yang dipelajari (Ningsih et al, 2015). Menurut Nurwahidah, et al (2012), penerapan pembelajaran Reciprocal Teaching berbasis kooperatif dapat meningkatkan pemahaman konsep fisika siswa kelas $\mathrm{X}$. Hal ini juga sesuai dengan pendapat Nashrullah, et al (2015), menyatakan bahwa pemahaman konsep siswa kelas eksperimen lebih bagus daripada kelas kontrol.

Selain pemahaman konsep siswa, model POGIL dengan media kartu masalah juga mempengaruhi aktivitas belajar siswa. Data aktivitas belajar siswa didapatkan dari instrumen aktivitas belajar siswa yang dilakukan oleh observer selama 4 pertemuan. Penilaian aktivitas belajar siswa disesuaikan dengan pembelajaran yang berlangsung, sehingga observasi dilakukan pada aktivitas yang tampak saja di dalam pembelajaran. Adapun aktivitas yang diamati selama pembelajaran dengan model POGIL dengan media kartu masalah adalah visual activities (memperhatikan penjelasan guru); oral activities (mengajukan pertanyaan, menjawab pertanyaan, mengkomunikasikan hasil diskusi), listening activites (mendengarkan presentasi atau pendapat teman); writing activities (mencatat hasil diskusi atau percobaan); motor activites (melakukan percobaan), dan Mental Activities (menganalisis data, menarik kesimpulan).

Uji normalitas dilakukan sebelum melakukan uji independent sample t-test dengan bantuan program SPSS 22, hal ini dilakukan untuk mengetahui bahwa data yang digunakan berasal dari data yang memiliki varian sama, artinya data terdistribusi normal. Berdasarkan uji normalitas diketahui bahwa kelompok data tersebut terdistribusi normal, maka pengolahan data yang digunakan adalah statistik parametrik dengan menggunakan Independent sample t-test.

Berdasarkan analisis independent sample t-test di dapatkan nilai Sig. (2-tailed) adalah sebesar $0,001 \leq 0,05$. Pengujian hipotesis yang digunakan adalah pengujian hipotesis pihak kanan, sehingga nilai signifikansi (2 tailed) dibagi 2 dan diperoleh signifikansi (1 tailed) sebesar 0,0005. Nilai 
signifikansi $0,0005 \leq 0,05$ maka $H_{a}$ diterima dan $H_{0}$ ditolak. Berdasarkan pedoman pengambilan keputusan bahwa rata-rata nilai aktivitas belajar siswa kelas eksperimen lebih baik daripada kelas kontrol. Sehingga dapat disimpulkan bahwa model POGIL dengan media kartu masalah berpengaruh secara signifikan terhadap aktivitas belajar siswa.

Secara singkat skor rata-rata aktivitas belajar siswa dengan menggunakan model POGIL dengan media kartu masalah dibandingkan dengan model yang biasa digunakan di sekolah dapat dilihat pada Tabel 2 berikut.

Tabel 2. Rata-rata skor indikator aktivitas belajar siswa

\begin{tabular}{|c|c|c|c|}
\hline No & Indikator & Kelas Eksperimen & Kelas Kontrol \\
\hline 1. & $\begin{array}{l}\text { Visual Activities (Memperhatikan } \\
\text { penjelasan guru) }\end{array}$ & 87 & 86 \\
\hline 2. & $\begin{array}{c}\text { Oral Activities (Mengajukan } \\
\text { pertanyaan) }\end{array}$ & 61 & 45 \\
\hline 3. & $\begin{array}{c}\text { Oral Activities (Menjawab } \\
\text { pertanyaan) }\end{array}$ & 68 & 54 \\
\hline 4. & $\begin{array}{c}\text { Oral Activities } \\
\text { (Mengkomunikasikan hasil diskusi) }\end{array}$ & 78 & 71 \\
\hline 5. & $\begin{array}{c}\text { Listening Activities (Mendengarkan } \\
\text { presentasi atau pendapat teman) }\end{array}$ & 85 & 82 \\
\hline 6. & $\begin{array}{c}\text { Writting Activities (Mencatat hasil } \\
\text { percobaan) }\end{array}$ & 75 & 70 \\
\hline 7. & $\begin{array}{c}\text { Motor Activities (Melakukan } \\
\text { percobaan) }\end{array}$ & 92 & 73 \\
\hline 8. & $\begin{array}{c}\text { Mental Activities (Menganalisis } \\
\text { data) }\end{array}$ & 75 & 67 \\
\hline 9. & $\begin{array}{c}\text { Mental Activities (Menarik } \\
\text { kesimpulan) }\end{array}$ & 77 & 67 \\
\hline
\end{tabular}

Dari Tabel 2 diketahui bahwa ratarata nilai aktivitas belajar siswa tertinggi adalah indikator melakukan percobaan (motor activities) dengan nilai 92\% untuk kelas eksperimen, dan indikator memperhatikan penjelasan guru (visual activities) mendapatkan nilai $86 \%$ untuk kelas kontrol. Sedangkan indikator mengajukan pertanyaan (oral activities) mendapatkan nilai rata-rata terendah dengan nilai $61 \%$ untuk kelas eksperimen dan nilai $45 \%$ untuk kelas kontrol.

Berdasarkan Tabel 2 dapat dilihat bahwa pada kelas eksperimen diketahui indikator aktivitas belajar siswa yang tertinggi yaitu melakukan percobaan (motor activities). Hal ini dikarenakan siswa pada saat melakukan percobaan sudah bisa mempraktekan cara kerja dengan baik sesuai di LKS. Indikator terendah untuk kelas eksperimen dan kelas kontrol sama yaitu mengajukan pertanyaan (oral activities), karena pada saat proses pembelajaran siswa cenderung takut dan malu untuk bertanya sehingga siswa kurang mengajukan pertanyaan.

Pelaksanaan proses pembelajaran menggunakan model POGIL dengan media kartu masalah tidak terlepas dari adanya kendala, antara lain 1) ketersediaan waktu yang kurang memadai sehingga pembelajaran pembelajaran berjalan lebih cepat untuk menyesuaikan dengan rencana yang telah ditentukan; 2) ruang laboratorium yang kurang siap untuk digunakan sehingga praktikum harus dilakukan di kelas dan menjadikan situasi kurang kondusif untuk melakukan praktikum. Namun apabila 
semua faktor yang ada dalam pembelajaran ini dikelola dan dipersiapkan dengan baik maka sangat dimungkinkan tercapainya tujuan pembelajaran secara maksimal.

\section{SIMPULAN DAN SARAN}

Berdasarkan hasil penelitian dan pembahasan, maka kesimpulan penelitian ini menunjukkan bahwa 1) model Process Oriented Guided Inquiry Learning (POGIL) dengan media kartu masalah berpengaruh secara signifikan terhadap pemahaman konsep siswa di SMA; dan 2) model Process Oriented Guided Inquiry Learning (POGIL) dengan media kartu masalah berpengaruh secara signifikan terhadap aktivitas belajar siswa di SMA.

Berdasarkan hasil penelitian dan pembahasan, maka saran yang diberikan antara lain: (1) penerapan model Process Oriented Guided Inquiry Learning (POGIL) terdiri dari beberapa tahapan, sehingga diharapkan seorang guru harus mempertimbangkan waktu pembelajaran jadi diperlukan pengorganisasian siswa dengan sebaik-baiknya dalam setiap tahapan pembelajaran model POGIL agar proses dapat berjalan dengan efektif; dan (2) bagi peneliti lanjut, hasil penelitian ini diharapkan dapat dijadikan masukan untuk penelitian selanjutnya dengan pokok bahasan yang berbeda.

\section{DAFTAR PUSTAKA}

Arum, W.A.Y., Hartono, dan Sunarno.2017. Analisis Penerapan Model Pembelajaran Guided Discovery Ditinjau Dari Pemahaman Konsep Fisika Dan Aktivitas Belajar Siswa Kelas Xi Ipa Sma N 3 Wonogiri. Unnes Physics Education Journal. 6(1): 26-33.

Darmayanti, N. W. S., Sadia, W., dan Sudiatmika, A. A. I. A. R. 2013.
Pengaruh Model Collaborative Team work Learning Terhadap Keterampilan Proses Sains dan Pemahaman Konsep Ditinjau dari Gaya Kognitif. e-Journal Program Pascasarjana Universitas Pendidikan Ganesha Program Sains.3.

Ferdianto, F., dan Ghany. 2014. Meningkatkan Kemampuan Pemahaman Matematis Siswa Melalui Problem Posing. Jurnal Euclid. 1 (1): 47-54.

Hamdani, D., Kurniati, E., Sakti, I. 2012. Pengaruh Model Pembelajaran Generatif dengan Mengggunakan Alat Peraga Terhadap Pemahaman Konsep Cahaya Kelas VIII di SMP Negeri 7 Kota Bengkulu. Jurnal Exacta. 10(1): 79-88.

Jumarni, S., Sarwanto,dan D.F. Masithoh, 2013. Penerapan Pembelajaran Fisika Model Kooperatif Tipe Jigsaw Untuk Meningkatkan Aktivitas dan Hasil Belajar Fisika Siswa di SMP. Jurnal Pendidikan Fisika.1(2): 34-40.

Nashrullah, A., Hadisaputro, S., Sumarti, S.S. 2015. Keefektifan Metode Praktikum Berbasis Inquiry Pada Pemahaman Konsep dan Keterampilan Proses Sains. Unnes Chemistry in Education. 4 (2): 51-56.

Ningsih, S.M., Bambang, S., Sopyan, A. 2012. Implementasi Model Pembelajaran Process Oriented Guided-Inqury Learning (POGIL) Untuk Meningkatkan Kemampuan Berpikir Kritis Siswa. Unnes Physics Education Journal.1 (2): 44-53.

Ningsih, E.P., Siswoyo, Astra, M.I. 2015.. Pengaruh Metode POGIL 
(Pembelajaran Process Oriented Guided-Inqury Learning) Terhadap Keterampilan Proses Sains Siswa Pada Materi Suhu dan Kalor Kelas X SMA. Prosiding Seminar Nasional Fisika (E-Journal).4: 67-71.

Nurwahidah, I., Sarwi, dan Handayani, L. 2012. Penerapan Model Pembelajaran Reciprocal Teaching Berbasis Kooperatif Untuk Meningkatkan Pemahaman Konsep Fisika Siswa Kelas X. Unnes Physics Education Journal.1 (2): 54-59.

Rusilowati, A. 2006. Profil Kesulitan Belajar Fisika Pokok Bahasan Kelistrikan Siswa SMA di Kota Semarang. Jurnal Pendidikan Fisika.2 (2):100-106.

Sugiyono. 2016. Statistika Untuk Penelitian. Bandung: Alfabeta.
Sutarto dan Indrawati. 2013. Strategi Belajar Mengajar Sains. Jember: Jember University Press.

Wahyuni, S. 2011. Petunjuk Praktikum Evaluasi Hasil Belajar. Tidak Diterbitkan. Modul. Jember: Laboratorium FISDAS FKIP UNEJ.

Widyaningsih, Hariyono, dan Saputro. 2012. Model Mfi dan POGIL Ditinjau dari Aktivitas Belajar dan Kreativitas Siswa. Jurnal Universitas Sebelas Maret.1 (3): 266-275.

Wijayanti, P.I., Mosik, Hindarto, N. 2010. Eksplorasi Kesulitan Belajar Siswa Pada Pokok Bahasan Cahaya dan Upaya Peningkatan Hasil Belajar Melalui Pembelajaran Inquiry Terbimbing. Jurnal Pendidikan Fisika Indonesia. 6: 1-5. 